\title{
5 \\ In Search of a Profitable Pacific
}

I join the Australian Argonauts in their search for the land of the golden cocoa-nut. They are the genuine article all righthard-handed anxious-faced men-shearers, mechanics, miners, farmers, prospectors, out-back men, and a few born wanderers never happy unless they are on the move ... They very often got a spear through them, and they invariably had a bad time but they saw the world. A lot of these settlers were like walk-about blacks and if a new venture were started at the North Pole they would be off to it. ${ }^{1}$

Commissioned by an Australian shipping company to report on a newly established settlement scheme to the New Hebrides in 1902, Paterson-a poet and journalist-used extracts from his diary in an unpublished radio script for the Australian Broadcasting Commission. More commonly known by his pseudonym, Banjo, Paterson's reflections on the voyage of a group of prospective settlers from Sydney to the New Hebrides are often overlooked in light of his contribution to rural Australia and bush mythology. His brief visit to the Pacific offers a momentary glimpse into the diverse range of motives that underscored Australian travel, as well as shaped how the Islands were perceived. Australians were not the only travellers in the Pacific motivated by commercial success, but their travel writing played a significant role in encouraging Australian

1 This quotation was taken from a radio transcript; Andrew Barton Paterson, 'The Pioneers', TalksAB Paterson, Australian Broadcasting Commission (Sydney: ABC, 1935) (series no. SP 1558/2, 629, National Archives of Australia), 2. 
investment and public interest during a crucial time in the new nation's growth. Situated at the periphery of an empire at the turn of the century, Australia was poised to take advantage of the economic opportunities that other colonial powers were unwilling or unable to grasp. Opportunistic workers were at the forefront of Australias expansion into the neighbouring regions. As literary figures, these workers became emblematic of Australian nationalism, progress and development abroad. To what extent did these workers, and the travel accounts that described them, contribute to the dominant narrative of the Pacific Islands as a lucrative location for Australian commercial enterprise?

The enterprising Australian worker visited the Pacific Islands in search of opportunities for economic and social betterment, well before others arrived to travel for leisure. The masculine and heroic figure of the intrepid trader, prospector, overseer or farmer was the most frequent type of colonial Australian traveller in the nineteenth century. It was not until after World War I that tourists began to outnumber them. Accounts written by these workers were distinct from those written by leisure travellers. Simultaneously caught between two worlds, these workers often occupied the position of mediator in European-Islander relationships. Their close encounters and day-to-day observations of the Islands differentiated their accounts from the shallow, touristic impressions of the region and its peoples. Often self-motivated, their descriptions were distinctive from the biases that missionary and government records were subject to. Of course, their accounts were not always honest or accurate, but their close experiences with Pacific Islanders legitimised their authority as Pacific experts in Australia. This authority underscored the popularity of accounts that were written by these opportunists-cum-writers when they returned home.

Commerce historically motivated initial contacts between colonial Australians and the Pacific. Traders and seamen were among the first to pioneer new routes to, and create relationships with, the Pacific Islands in the nineteenth century. These economic ventures exploited, and often exhausted, certain Pacific Island resources - such as whales, seals, pearls, meat, sandalwood, copra, bêche-de-mer and other seafood, fruits, sugar, gold and even people (see Figure 17). As Australian economic enterprises expanded in Melanesia, larger companies consolidated small-scale operations and increased their profits by monopolising inter-island trade, as well as the production of copra, sugar, gold and phosphate. For this reason, Thompson argued that 'Australia's informal economic empire was 
dominant in Fiji, the Solomon Islands and the Gilbert and Ellice Islands'. Nickel exports from New Caledonia were also valuable to Australia, but they were controlled by the French. Firms with significant Australian capital or ownership included:

- Sydney-based traders, Burns, Philp and Company and W. R. Carpenter and Company

- Fiji-based traders, Morris Hedstrom

- Sydney-based copra firms, On Chong and Lever Brothers (who owned plantations in the Solomon Islands)

- Colonial Sugar Refinery (CSR) in Fiji, which was headquartered in Melbourne

- Australian-owned Emperor Gold Mining Company and Loloma Gold Mines in Fiji

- Melbourne-based Pacific Islands Company (later known as the Pacific Phosphate Company), which mined Banaba and Nauru for phosphate.

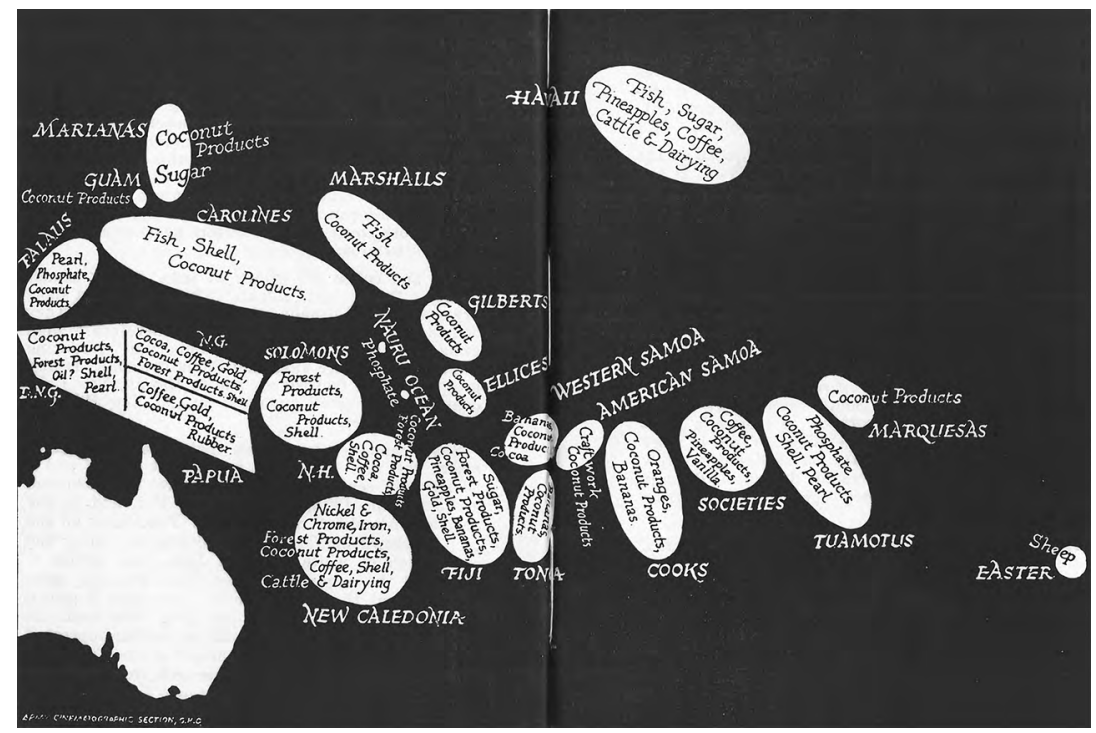

Figure 17: Products of the Pacific Islands.

Source: Australian Army Education Service, The Pacific Islands (Melbourne: Army Education Service, 1942), 10-11.

2 Thompson, Australia and the Pacific Islands in the Twentieth Century, 30-1. 
Many of these businesses played an essential role in encouraging Australian notions of empire, whether by lobbying governments or by publishing propaganda. Only in Papua and New Guinea were Australian imperial ambitions realised, and these two territories subsequently became valuable sources of gold, rubber and copra. ${ }^{3}$

Popular notions of Pacific commerce in travel writing can be traced chronologically from their starting point in the late nineteenth century, when notions of the masculine and heroic colonial Australian worker began to emerge. These notions continued into the twentieth century, when the Australian worker was appropriated as a promotional tool for the economic exploitation of the region. This imagined ideal did not match the lived experiences of those Australians who worked in the Islands in the early twentieth century. One of the first authoritative writers about the Pacific who came from the Australian colonies was Louis Becke. He played an influential role in understanding the nineteenthcentury's romanticisation of the life of a European working in the Pacific. Becke's representation of the trader and planter formed the groundwork for a body of travel literature in the twentieth century that imagined the Pacific as a region full of economic potential for Australian enterprise.

\section{Louis Becke, the Archetypal Australian Trader}

Louis Becke was the most famous travel writer of the late nineteenth century in colonial Australia. His significant contributions as a writer and as an expert on the Pacific have been acknowledged in the biographies compiled about him, as well as in various literature studies. ${ }^{4}$ Born in 1855 in Port Macquarie, New South Wales, George Lewis Becke first encountered the Pacific when he travelled to San Francisco with his brother at the age of 14. Two years later, he stowed away on the Rotumah, bound for Samoa, where he worked as a bookkeeper in a local trading store. Over 20 years, Becke worked throughout the Pacific; he was a supercargo (representative of a vessel's owner) in the North Pacific, a resident trader in the Gilbert Islands

3 Nelson, Black, White and Gold, 11-12.

4 Arthur Grove Day, Louis Becke (Melbourne: Hill of Content, 1967); Henry Evans Maude, 'Review Article: Louis Becke: The Traders' Historian', The Journal of Pacific History 2, no. 1 (1967): 225-7, doi.org/10.1080/00223346708572118; Thomas and Eves, Bad Colonists; Dixon, Writing the Colonial Adventure; Sturma, South Sea Maidens. 
and a performer of various short-term jobs in New Britain, the Marshall Islands and New Caledonia. Unable to find regular work in 1892, Becke turned to writing. He found employment with the Sydney-based periodical The Bulletin, with his first story appearing in 1893. In 1894, Becke's first collection of stories was published under the title By Reef and Palm, which launched him into the spotlight. Becke subsequently gained local and international commercial success and published a further 34 books and numerous articles in newspapers and magazines, earning the reputation of 'Rudyard Kipling of the Pacific'. 5 Although others tried to emulate his success, Becke's international popularity and his influence on Australian notions of the Pacific region were exceptional.

Becke's literary success has been attributed to his firsthand knowledge of the Pacific as much as to his writing style. The lived experiences of traders and seamen inspired fictional tales of adventure for children and adults, many proliferating from England and English authors in the late nineteenth century. ${ }^{6}$ Although Becke's subject matter conformed to other English adventure fiction (i.e. pitting courageous white men against 'savage' people), his work also represented a departure from the romanticism and moral justifications of previous English literature. This proved to be popular among the colonial Australian audiences who welcomed the 'authentic' realism of his stories (which he based on actual experiences). ${ }^{7}$ In England, he was considered an authority on the South Seas, with his main publisher, T. Fisher Unwin, producing multiple editions for the British and colonial markets. As Helen Bones has demonstrated, a healthy market for the 'colonial exotic' existed at the time. ${ }^{8}$ Many of Becke's stories were published as collections of short and unconnected tales, similar to sailors' yarns, with a narration that was abrupt, intense and dramatic. Although his tales were often fictional, Henry Evans Maude, Nicholas Thomas and Richard Eves have highlighted the historical experiences of Becke's life that had underscored many of his stories.'

Becke's style of writing was nurtured and influenced by Jules Francois Archibald, the editor of The Bulletin. It both reflected and contributed to a new literary culture that was growing in Sydney from the 1890s. Under

5 Day, Louis Becke, 63.

6 Dixon, Writing the Colonial Adventure, 185. See also Saxby, A History of Australian Children's Literature.

7 Dixon, Writing the Colonial Adventure, 180.

8 Bones, 'Travel Writers and Traveling Writers in Australasia', 83.

9 Maude, 'Review Article: Louis Becke: The Traders' Historian', 226; Thomas and Eves, Bad Colonists. 
Archibald's leadership, The Bulletin encouraged new Australian authors from the Australian colonies, rather than relying on overseas articles. It also fostered a patriotic, protectionist, masculine and racist literature. ${ }^{10}$ From its first issue until the early 1960s, 'Australia for the White Man' was written on its masthead. The Bulletin editors preferred realism over romance, with the latter being considered 'foreign, unmanly and unsuited to expressing radical, egalitarian and nationalistic ideas', as argued by Robert Dixon. ${ }^{11}$ The Bulletin's popularity ensured that its notions about the Pacific were widely circulated. By 1900, its circulation was already 80,000 . Its success continued until a decline after World War I. ${ }^{12}$ Despite being regarded as the 'bushman's bible', it did publish articles about the Pacific Islands, with many of its contributors also writing Pacific fictions and travelogues elsewhere (e.g. Ion Idriess, Vance Palmer, Dale Collins, Lewis Lett, Albert Dorrington and Norman Lindsay).

The Bulletin's content incorporated and encouraged popular notions about Australian masculinity and national character that had been developing from the 1880s. Marilyn Lake identified The Bulletin as a domain in which the 'gender wars' of the 1890 s were enacted; she drew further attention to the magazine's 'masculinist' representations of the iconic Australian 'bushman' and the response garnered from feminist social reform campaigners. ${ }^{13}$ In this environment, Australian literature overwhelmingly presented the nation as young, pure and innocent. In the figure of the 'coming man', it idealised a people who were superior to the British stock, shaped by the Australian climate and proven in sports and war. This coming man displayed independence, manliness, a fondness for sport, egalitarianism, a dislike of mental effort, self-confidence, a certain disrespect for authority. ${ }^{14} \mathrm{He}$ was embodied by the lifesaver and the noble worker - and, later, by the soldier or 'digger'. In a similar way that the Australian bush was regarded as shaping the coming man, so too could the tropics be a proving ground for the Australian character.

10 Denoon, 'Re-Membering Australasia: A Repressed Memory', 298.

11 Dixon, Writing the Colonial Adventure, 184.

12 Garry Wotherspoon, 'The Bulletin', Dictionary of Sydney, dictionaryofsydney.org/entry/the bulletin.

13 Marilyn Lake, 'Historical Reconsiderations IV: The Politics of Respectability: Identifying the Masculinist Context', Historical Studies 22, no. 86 (1986): 116-31, doi.org/10.1080/10314618608 595739.

14 White, Inventing Australia, 77, 117. 
Becke's writing conformed to these masculine ideals, often presenting European traders, prospectors, planters and sailors as protagonists. Whether villainous or heroic, Becke's characters were men of action rather than romantics, and women often appeared only as love interests in formulaic interracial dramas. ${ }^{15}$ This representation acquired greater significance in the parts of the Pacific in which colonial Australians were actively involved (e.g. Papua and New Guinea). Historian Nigel Krauth wrote that Becke:

Established the pattern of the New Guinea colonial short story: its superficially tough male characters, its dangerously enervating female characters, its constant theme of white survival, its avoidance of the ethics of that survival in practice, its description of an environment devoid of divine assistance, and its bloodbespattered adventure drama. ${ }^{16}$

Becke's tales frequently focused on the trader, often through his alter ego, Tom Denison, and in the popular tales of villainous American labour trader, 'Bully' Hayes. Due to their transient nature, traders lent themselves to fictional tales, allowing writers to situate them in various exotic locations that contained different actors and new adventures. They were distinct from the nineteenth-century beachcomber, who had completely abandoned 'civilisation', or the government official and missionary, who were constrained by specific regulations and expectations pertaining to their jobs. Rather, Becke focused on the enterprising Australian pioneerthe trader, miner, farmer and businessman — who traversed and acquired the Pacific region. This predominantly male figure was heroic and noble, portrayed in literature as adventurous, ambitious and grappling with the dilemma of maintaining civilised standards in a savage environment. Becke described this figure as:

Generally a rough character-a runaway from some Australian or American whaler, or a wandering Ishmael who, for reasons of his own, preferred living among the intractable, bawling, and poverty-stricken people of the equatorial Pacific to dreaming away his days in the monotonously happy valleys of the Society and Marquesas Groups. ${ }^{17}$ 
Becke's tales often characterised traders as protagonists due to the dramatic tension that was achieved by focusing on their struggle to negotiate between two cultures. As one of Becke's fictional characters said:

Had I gone back to Sydney, where would I be now?-a mate, I suppose, on some deep-sea ship, earning $£ 12$ or $£ 14$ a month. Another year or two like this and I could go back a made man ... No, I'll stay here: 'Kapeni Paranili' [his island name] will always be a big man in the Paumotus [Tuamotus], but Fred Brantley would be nobody in Sydney. ${ }^{18}$

As such, they were popular protagonists for interracial romances (By Reef and Palm was a collection of entirely interracial romances published in 1894, to great acclaim) or for stories in which they crossed from civilisation to savagery. Like previous European literature about interracial romances, the possibility of an interracial relationship was alluring, yet ultimately forbidden. These fictional romances thus rarely offered positive outcomes. However, this focus on romance influenced popular imaginings of Australians who lived in the Pacific. Paterson wrote:

Everyone recalled Louis Becke's sketches of traders, languid, cultivated men of leisure, whose talk was mostly about square gin, and whose occupation was mostly fighting over the affections of brown maidens. ${ }^{19}$

Becke's trading tales contributed to a popular perception of Europeans who lived and worked in the Pacific Islands. This romanticised image of the trader, planter or overseer infiltrated everyday travel accounts about the Pacific Islands, as tourists were keen to meet a Becke-like trader or plantation owner face to face. Even before they arrived at the Islands, travellers encountered traders on ships and at ports on their way to the Pacific. In 1921, Ralph Stock described how several traders crowded the ships at Norfolk Island as they returned from the New Hebrides. ${ }^{20}$ In light of the tourism industry that was commencing in the Islands, companies would organise day trips to local missions and plantations. White residents, either looking forward to good company or hoping to gain some financial benefit, welcomed visitors and offered tours around their properties. Marshall described this process in detail:

18 Becke, By Reef and Palm, 174-5.

19 Andrew Barton Paterson, 'The New Hebrides: The New Pilgrims' Progress', Sydney Morning Herald, 26 July 1902, 12, nla.gov.au/nla.news-article14471684.

20 Stock, The Cruise of the Dream Ship, 141. 
Throughout the South Seas you'll find them; little kingdoms wedged between a green wilderness ... you will see a central group of buildings near the beach, flanked by an ordered forest of perhaps a hundred thousand coconut-palms ... If it is steamertime, when most visitors arrive, your most vivid impressions will be a harassed figure in soiled white ... Sail in on any other day in the month and you will be met by a hardy individual in shirtsleeves and a battered helmet, whose hospitality is as boundless as his capacity for conversation. He will suggest a drink and lead you to a shady thatched kiosk, and after lunch, if you are interested, will take you around the plantation. ${ }^{21}$

Marshall's observations were typical of those found in Australian travel accounts, which generally described residents as hardy workers (often emphasised by their alcoholism). Although occasionally criticised for succumbing to 'uncivilised' temptations, the resident European was mostly respected by visitors for his hospitality and resilience. ${ }^{22}$

Travellers also regularly admired the life of a plantation overseer. These men appeared wealthy and successful, possessing large, spacious houses, 'picturesque' grounds, well-behaved servants and employees, and an abundance of resources. Marshall observed that 'the planter, perhaps a white storekeeper, and usually a half-caste overseer, constitute an oligarchy which rules the coconut kingdom and its hundred-odd coloured labourers'. ${ }^{23}$ The lives of plantation overseers were regarded as being carefree and unburdened. As Julian Thomas noted, 'From the point of view of a cane-bottomed chair and a full tumbler, a planter's life in the New Hebrides was one to be envied'. ${ }^{24}$

This romantic image of the life of a European or Australian resident in the Islands became increasingly irrelevant by the twentieth century. By his own admission, Becke's trading fantasies in the Pacific were nostalgic. He reminisced that the nineteenth-century 'wave-punchers' were different from the new steamers that 'exploited' the Islands for trade. ${ }^{25}$ Not only had transportation routes and trade goods changed but so too had the Islands. Popular tales of lone pioneering individuals living among supposedly savage and dangerous Islanders may have resonated with the experiences

21 Marshall, The Black Musketeers, 281.

22 Marshall, The Black Musketeers, 289.

23 Marshall, The Black Musketeers, 283.

24 Thomas, Cannibals and Convicts, 222.

25 Becke, By Reef and Palm, 97. 
of colonial Australian sandalwood and labour traders of the nineteenth century; however, by the 1900s, Islanders and Australian visitors were more familiar with one another. Although instances of violent encounters were less frequent, Australian travellers continued to imagine the trader, planter, overseer or miner as heroic and successful in the twentieth century. This was partly due to the persistence of conventional European notions of the Pacific's economic potential-a concept that was encouraged by Australian governments and businesses who wished to promote investment and expand commerce in the region.

\section{Economic Potential in the Pacific}

Becke's exciting tales of trading adventures linked to a wider narrative that had traditionally imagined the Pacific Islands as a region of unknown riches and prosperity. These idealistic descriptions were persistent from the 1880 s to the 1940s and were indiscriminately applied to all the Pacific Islands. This trope was underscored by a European literary tradition of imagining the Pacific as an idyllic paradise, in which Australians' unfamiliarity with many of the Islands assisted with the perpetuation of this image. Travellers such as Henry Tichborne, who 'began to dream of new El Dorados', exaggerated the potential rewards that were hidden within the Islands and encouraged expectations of finding paradise, gold or other treasures that had yet to be tapped. ${ }^{26}$ In addition to descriptions of gold mining and pearl diving, travel accounts often included vivid imagery of jewels and gold to describe the Pacific Islands. In 1900, Ernest Osborne described an atoll of the Gilbert Islands as a 'gemlike idyll', and in 1927, Arnold Safroni-Middleton observed that the mountains of Fiji 'have become storied windows of nameless crimson hues and burnished gold'. ${ }^{27}$ This imagery also hinted at travellers' subconscious desires to possess these rich Islands, as Elinor Mordaunt did in 1926, when she described the Islands:

All in the little, small as a jewel, so that it seems as though one were able to take it up in the hollows of one's two hands, feel the warmth of it, turning it, catching the glow upon it as upon a jewel. ${ }^{28}$

26 Tichborne, Rambles in Polynesia by Sundowner, 74.

27 Ernest Osborne, Through the Atolls of the Line (Five Dock: publisher unknown, 1900); SafroniMiddleton, Tropic Shadows, 20.

28 Mordaunt, The Venture Book, 328. 
As well as the direct allusions to gold and other minerals, Australian travellers noted the abundance and fertility of the land - with its propensity for fruit and vegetation, the richness of the soil and the value of the goods that could be garnered. JB Nicoll, a tourist on a cruise through the Solomon Islands in 1902, was relieved 'to see the signs of cultivation and clearing after looking at so much virgin forest'. ${ }^{29}$ In 1909, Presbyterian minister Charles Stuart Ross noted that Fiji possessed 'a large area of wonderfully fertile soil that is hardly equalled ... [which] have been yielding annually crops of cane, cotton, maize, tobacco and other products without manure and without apparent impoverishment. ${ }^{30}$ In 1920, businessman Frank Coffee wrote about the Solomon Islands, stating that:

All trade is done with Australia. With copra and other products exported, and merchandise imported, the amount runs to hundreds of thousands of value a year, and the war has not made any appreciable difference. ${ }^{31}$

These observations emphasised the development of business and industry in the Islands in the 1900s, as well as reinforced Australian perceptions of the Pacific Islands as being ready for taking. Aside from the obvious descriptions of natural resources, travellers also commented on the suitability of the tropical climate for Europeans and on the utility of Islanders as labourers. These issues were highly contested in Australian travel accounts because conventional stereotypes of the inherently lazy or savage Islander-as well as popular fears of the potentially dangerous tropical environment-contradicted efforts to promote business and settlement in the Islands. The labour issue also informed debates about the supposed indigenous depopulation of the Pacific.

Other travel publications also focused on economics and trade as a major feature of the Pacific Islands. This reflected the growing interest of Australian businesses, investors and governments in the potential resources of the Pacific Islands in the early 1900s. Travel guides such as the Pacific Islands Yearbook provided detailed economic overviews that listed imports and exports figures for each Island group, as well as current market prices and tariffs. The first edition in 1932 included an article by the editor, Robert William Robson, who described the 'opportunities for new settlers

29 JB Nicoll, 'A Cruise through Some of the Pacific Islands in 1902 by Mr and Mrs J. B. Nicoll', The Life and Adventures of George Robertson Nicoll, 1824-1890, MS 3292 (Canberra: National Library of Australia, 1902), 24.

30 Ross, Fiji and the Western Pacific, 289.

31 Coffee, Forty Years on the Pacific, 111. 
in the Pacific'; he noted that the Pacific Islands were 'enormously rich in natural resources' and were awaiting 'men of pluck, vision, determination and moderate capital'. ${ }^{32}$ Shipping and trading companies also published their own travel ephemera and regularly commissioned travel writers to compose favourable articles. As part of BP's successful expansion from its Australian coastal operation into Pacific trade and shipping, its quarterly magazine, BP Magazine, began to encourage tourism while simultaneously promoting itself as an informative and educative magazine. In its earliest editions during the 1910s, Picturesque Travel characterised the Pacific Islands as a primitive holiday destination, marketing the resident trader or planter as an exotic attraction to potential tourists. For example, a 1914 issue advertised a guided 'walk through the Government plantations' and 'a round of visits' to the local rubber and coconut plantations in the Solomon Islands. ${ }^{33}$ BP Magazine later began publishing articles specifically about trade in the Pacific, explaining particular industries and the goods and wealth that they produced. Articles had titles such as 'Coconuts and Copra', 'Pearl Shelling in the Torres Strait' and 'Phosphate Island'. ${ }^{34}$ Efforts to promote the company's trading operations by showing examples of industry and labour in the Pacific were mediated by images of idyllic relaxation and natural landscapes that advertised its tourist cruises.

BP's rapid expansion in the Pacific ensured that it became a powerful and influential Australian company by the 1900s. Historian Judith A Bennett noted that 'to a world largely ignorant of island conditions the semimonthly steamer was a continued source of information. It became the [Solomon Islands] protectorate's unofficial publicity agent in Australia'. ${ }^{35}$ The company's political influence was widely acknowledged by Australians at the time. Paterson described one of its founders, James Burns, 'as near to an Empire builder as we ever saw in these parts' and noted that:

Anywhere that there was a risk to be run and money to be made you would see the flag of James Burns. If he had been dealing in diamonds instead of copra and bananas, he might have been another Cecil Rhodes's understudy. ${ }^{36}$

32 Robson, The Pacific Islands Yearbook, 9.

33 Burns, Philp \& Company, Limited, Picturesque Travel, no. 4 (1914), 40, 42.

34 BC Criswick, 'Coconuts and Copra', BP Magazine 1, no.4 (September 1929): 44; JL Adams, 'Pearl Shelling in the Torres Strait', BP Magazine 2, no. 2 (March 1930): 48; Taupo, 'Phosphate Island', BP Magazine 11, no. 4 (September 1939): 2.

35 Judith A Bennett, Wealth of the Solomons: A History of a Pacific Archipelago, 1800-1978 (Honolulu: University of Hawai' i Press, 1987), 126-7.

36 Andrew Barton Paterson, 'Banjo Paterson Ends His Story: Political Giants and "Pilgrim Fathers"', Sydney Morning Herald, 4 March 1939, 21, nla.gov.au/nla.news-article17573640. 
BP's periodicals were one part of a diverse strategy to justify and extend the company's reach throughout the Pacific Islands. Although scholars may presently debate the merits of these commercial publications as examples of travel writing, their popularity among a broad readership meant that they influenced subsequent travel accounts by reinforcing particular themes.

Other Australian periodicals concerned with the Pacific Islands devoted much of their content to issues of trade and commerce. The Pacific Islands Monthly from 1930 to 1945 included 148 general articles on agriculture, 74 on commerce and 205 on the economy, not including those articles about trade in specific Islands. ${ }^{37}$ A similar focus can be observed in Walkabout, a monthly geographic magazine that was published by the Australian National Travel Association from 1934. ${ }^{38}$ Walkabout's interest in primary industries and rural development in remote Australia and the Pacific is evidenced by many articles that stressed the region's 'beckoning potential'. They informed readers about the lives of Island residents and the processes involved in certain industries. ${ }^{39}$ Articles about coconut plantations were most common, but titles also included 'The Story of Nauru', 'Vanua-Lava and its Sulphur', 'Life on a Coco-Nut Plantation', 'Tuamotu Archipelago: Amongst the Pearl Divers', 'The Coco-Nut Tree', 'Cannibals and Talkies' (about a plantation owner), 'The Tricolour in the South Seas' (about French mining) and 'Fiji Gold'. ${ }^{40}$ These were all positive portrayals of life as a trader or planter, as William C Groves noted: 'What a wonderful life these plantation chaps have. I'd give the world to exchange places with that chap we met to-day.' ${ }^{31}$

Although these examples may reflect the visibility of Australian business and settlement in the Pacific by the 1930s, a brief survey of earlier periodicals with Pacific content suggests that Australian readers were

37 Margaret Woodhouse and Robert Langdon, Pacific Islands Monthly Cumulative Index: Volumes 1 to 15 [August, 1930 to July, 1945] (Sydney: Pacific Publications, 1968). Most of these articles discussed the copra trade.

38 Quanchi, 'Contrary Images', 78.

39 Johnston and Rolls, Travelling Home, Walkabout Magazine, 105.

40 William J Dakin, 'The Story of Nauru', Walkabout 1, no. 5 (March 1935): 32-6; DS Askew, 'Vanua-Lava and its Sulphur', Walkabout (April 1935): 26-7; William C Groves, 'Life on a Coco-Nut Plantation', Walkabout (May 1935): 33-6; Mordecai Baruch, 'Tuamotu Archipelago: Amongst the Pearl Divers', Walkabout (January 1936): 45-7; Gerard Dillon, 'The Coco-Nut Tree', Walkabout (June 1937): 27-8; Winston H Burchett, 'Cannibals and Talkies', Walkabout (October 1938): 41-4; Basil Hall, 'The Tricolour in the South Seas', Walkabout (December 1939): 17-20; FI Ryan, 'Fiji Gold', Walkabout (August 1940): 15-18.

41 Groves, 'Life on a Coco-nut Plantation', 33. 
interested in trade and commerce in the Islands much earlier. The Lone Hand (1907-1921), a sister publication of The Bulletin, published 22 articles about the Pacific Islands, 10 of which were about trade. This included articles such as 'Fiji Sugar Plantation', 'On a Fijian Cocoanut Plantation', 'Ocean Island and the Phosphate Industry', 'Australia and the Nauru Phosphate Deal' and 'Trading in the South Seas'. ${ }^{42}$ Additionally, the Sea, Land and Air magazine- which focused mainly on transportation technology between 1919 and 1923-published 27 articles with Pacific Island topics, and six focused on trade or economics. Titles include 'Nauru Island', 'Isles of Pearl and Gold', 'Copra: A Gigantic Tropical Industry', 'Waters of Adventure' and 'Cocoanut Industry in the South Pacific: Its Growth and Possibilities. ${ }^{43}$ This reflects a broader and popular interest in Pacific trade, as well as a patriotic view of Australia's ability to garner these resources. Some magazines emphasised this economic potential as part of a nationalistic message that advocated for Australian development, progress and empire. ${ }^{44}$

Although these general observations may have overwhelmingly presented the Pacific Islands as a region of wealth and prosperity, it is also important to consider the specific historical contexts in which individual observations were made. The attraction of economic prosperity in the Pacific fluctuated in accordance with periods of economic strife in Australia and the Pacific (e.g. the Great Depression). Edward Way Irwin and Ivan Goff left lucrative jobs in Perth in the 1930s to search for adventure; instead, they found depression and unemployment in Fiji. They described struggling to find jobs in Suva, pawning their belongings and raiding the pantry of the boarding house in which they stayed. In their travel account, they wrote: 'Half of Suva was waiting for something to turn up-and so was half the world, it seemed'. ${ }^{45}$ John Archibald Fraser, a gold prospector in Fiji, described fluctuations in the number of gold prospectors coming from Australia once news of a new discovery was released. Between 1933

42 'Fiji Sugar Plantation', Lone Hand (February 1909): 455; Ralph Stock, 'On a Fijian Cocoanut Plantation', Lone Hand (March 1912): 349; 'Ocean Island and the Phosphate Industry', Lone Hand (November 1912): 42; 'Australia and the Nauru Phosphate Deal', Lone Hand (August 1920): 37; Captain Strasburg, 'Trading in the South Seas', Lone Hand (November 1918): 508.

43 Thomas J McMahon, 'Nauru Island', Sea, Land and Air 1, no. 11 (February 1919): 656-60; Frank Reid, 'Isles of Pearl and Gold', Sea, Land and Air 3, no. 36 (March 1921): 759-61; Kat McDowell, 'Copra: A Gigantic Tropical Industry', Sea, Land and Air 4, no. 38 (May 1921): 97-101; Frank Reid, 'Waters of Adventure', Sea, Land and Air 4, no. 39 (June 1921): 179-81; Thomas J McMahon, 'Cocoanut Industry in the South Pacific: Its Growth and Possibilities', Sea, Land and Air 4, no. 47 (February 1922): 813-6.

44 White, Inventing Australia, 115.

45 Irwin and Goff, No Longer Innocent, 93. 
and 1935, Fraser observed the sudden revival of Australian interest in prospecting, noting that 'most of the people we met in Fiji at that time were more or less infected with gold-fever'. ${ }^{46}$ Fluctuations in the global economy could also affect Pacific Island economies, such as the fall in copra prices during the 1930s Depression and the general decline in Island trade during the interwar years. ${ }^{47}$

Fiji's proximity to Australia, its British colonial status and its location as a key stopover destination in the Pacific entailed that Australians frequently encountered Australian enterprises there. CSR represented the largest Australian economic interest in the Pacific Islands in 1883, and by 1901, it had invested over $£ 2$ million in Fiji. ${ }^{48}$ Most of Fiji's imports came from Australia, mostly from New South Wales, prompting the Bank of New South Wales to open branches in Fiji. Australian companies were also invested in the Fiji copra trade and in the gold mining industry for a time. Beatrice Grimshaw's From Fiji to the Cannibal Islands directly addressed Fiji's economic potential in 1907. In Fiji, she claimed:

Withal, there were tens of thousands of acres all over the islands unused and unoccupied; white settlers and planters seldom or never came to try their luck, and the resources of this, the richest of all the rich Pacific archipelagoes, were not one-hundredth part developed. ${ }^{49}$

She later asked, 'Why should these great wastes of grass lie idle?' Such comments intentionally overlooked the prosperous indigenous population who lived on the land and further strengthened colonial claims to own and exploit it. This travel account was one of Grimshaw's many texts that blended personal narrative and commercial advice, as she was frequently commissioned by shipping companies and the Australian government to publish materials that emphasised the potential for economic development and the suitability for white settlement. She published eight prospectus pamphlets, as well as three travel accounts and fictional romances that were 'based on the endeavours of the new planter-settlers and the pioneering fortune-seekers'. ${ }^{50}$ Grimshaw did not disguise these ulterior motives from her readers. In her other travelogue, In the Strange South Seas, she wrote:

46 Fraser, Gold Dish and Kava Bowl, 155.

47 Bennett, Wealth of the Solomons, 218; Thompson, Australia and the Pacific Islands in the Twentieth Century, 94.

48 Thompson, Australian Imperialism in the Pacific, 164.

49 Grimshaw, From Fiji to the Cannibal Islands, 31.

50 Krauth, The New Guinea Experience in Literature, 4. See also Hugh Laracy, 'Beatrice Grimshaw (1870-1953): Pride and Prejudice in Papua', in Watriama and Co: Further Pacific Islands Portraits (Canberra: ANU E Press, 2013), doi.org/10.22459/WC.10.2013. 
To find out, as far as possible, what were the prospects for settlers in some of the principal Pacific groups, was the main object of my journey to the Islands. It had always seemed to me that the practical side of Pacific life received singularly little attention, in most books of travel. ${ }^{51}$

Grimshaw was not alone in publishing commercial agendas within travel narratives. Albert Fuller Ellis_-an Australian-born prospector who published an account of the phosphate industry in Ocean Island and Nauru at this time-also blatantly emphasised the wealth that could be found in these Islands, which were valuable assets to Australian agriculture and business. ${ }^{52}$ The colonial names for Banaba and Nauru belied the devastating environmental damage that was done to the Islands as a result of extensive phosphate mining operations headed by the British-owned Pacific Islands Company (later the Pacific Phosphate Company). These companies employed Australian workers, were headquartered in Australia and exported valuable quantities of phosphate for Australian agricultural use as fertiliser. ${ }^{53}$ Both Islands were far from the Australian coast and were relatively small; they were thus rarely visited by Australian travellers, other than those employed by the mining company. These few descriptions of these Islands that featured in Australian literature usually focused on the benefits of mining, such as Thomas McMahon's article on Nauru in the Penny Pictorial, titled 'Lets-all-be-thankful Island'. ${ }^{4}$ As a journalist and freelance photographer, Thomas McMahon also contributed to a photograph series on the phosphate islands in The Queenslander in the same year. Historian Max Quanchi argued that McMahon's career illustrated 'the importance of photography in constructing a colonial and hegemonic representation' of the Pacific. ${ }^{55}$

Ellis's mixture of personal recollections and business history in two books overlooked the exploitation of the Islands' resources, as well as romanticised the role of the prospector:

51 Grimshaw, In the Strange South Seas, 51.

52 Albert Fuller Ellis, Ocean Island and Nauru: Their Story (Sydney: Angus \& Robertson, 1935); Albert Fuller Ellis, Adventuring in Coral Seas (Sydney: Angus \& Robertson, 1936).

53 Thompson, Australia and the Pacific Islands in the Twentieth Century, 30, 83, 93.

54 Thomas McMahon, 'Lets-All-Be-Thankful Island', Penny Pictorial (September 1919).

55 Max Quanchi, 'Thomas McMahon: Photography as Propaganda in the Pacific Islands', History of Photography 21, no. 1 (2015): 42-53, doi.org/10.1080/03087298.1997.10443716; Max Quanchi, 'To the Islands: Photographs of Tropical Colonies in The Queenslander' (paper, 18th Pacific History Association Conference, University of South Pacific, Suva, 2008), 4. 
Prospecting for phosphate gets into the blood ... for does it not bring one into close touch with lonely islands, frequently uninhabited, with their possibility of all sorts of discoveries and mysteries? ${ }^{56}$

In doing so, Ellis portrayed the Islanders as primitive and isolated and framed the mining operations as an adventurous endeavour that benefited all those involved. He argued that this was a process in which the Islanders were complicit, as well as one that they found agreeable; he noted that they were 'eager to come into closer touch with civilisation'.$^{57}$ Ellis emphasised the development that the mining created-which included the construction of buildings, schools, hospitals, sewers and water storage, as well as the provision of medicine, teachers, missionaries and governance. Consequently, 'it seemed as if a magic wand had been waved, transforming an enforced idle community into an industrious one'.$^{58}$ Ellis conveniently ignored the disputes between Australian administrators and Nauruans, as well as the devastating effects of the mining that ultimately stripped 90 per cent of the Islands' surfaces by the time it ceased operating in the 1980s. ${ }^{59}$

The British protectorate of the Solomon Islands was also profitable, its commerce being entirely with Sydney in 1904 and 1905. ${ }^{60}$ The copra trade was its most lucrative asset, with many Sydney or Brisbanebased companies invested in planting and trading operations there (most notably Lever Pacific Plantations and subsidiary companies of BP). This development of plantations in the Solomon Islands peaked between 1905 and 1913, with the popular idea of profits being made in the Island group encouraged by books and newspaper articles at the time. Bennett highlighted one full-page spread in the Sydney newspaper, The Sun, on 6 August 1910, titled 'The Wealth of the Solomons', which typified the promotions that encouraged Australian investment. ${ }^{61}$ The island-hopping schedule of shipping services to the Island group offered travellers opportunities to visit plantations and farmlands, where they would often repeat the narrative of economic prosperity. Coffee was one such traveller, who observed in 1920 that:

56 Ellis, Ocean Island and Nauru, 51.

57 Ellis, Ocean Island and Nauru, 58.

58 Ellis, Ocean Island and Nauru, 62.

59 Thompson, Australia and the Pacific Islands in the Twentieth Century, 93.

60 Thompson, Australia and the Pacific Islands in the Twentieth Century, 28-9.

61 Bennett, Wealth of the Solomons, 138. 
In the last twenty years the development has been marvellous ... There are many thousands of acres being developed into well laidout, well managed cocoanut plantations, some in the first stages, and others already come to fruitful and profitable stages. ${ }^{62}$

Such impressions could meaningfully influence audiences at home, especially when they were published with frequency, and their messages were reinforced with images. Quanchi identified one instance involving a series of articles and 60 photographs that were published in the regional newspaper, The Queenslander, in 1917-18 that renewed Australian interest in sub-imperialism in the Solomon Islands. ${ }^{63}$

Although Australian investment and industry in the New Hebrides were not as extensive as it was in the Solomon Islands or Fiji, Australian governments and businesses made considerable efforts to entrench the narrative of economic development there to contest French influence in the Island group. This narrative supported the economic subsidies and settlement schemes for Australians that were launched in response to widespread public opposition to the shared Anglo-French colonial rule from 1887. In the New Hebrides, fertile land and favourable economic conditions were advertised to attract potential settlement; this was part of a broader scheme to bolster British and Australian resident numbers in the Island group. The Australasian New Hebrides Company (ANHC), in which BP had a controlling share, was one company that pushed this narrative from 1889 until its collapse in 1897. In a propaganda pamphlet, it argued that:

Copra, coffee, ramiefibre, tea, spices and tropical fruits will be the principal produce, and in raising these a great exchange market for Australian produce and merchandise is opened up. The rich volcanic soil will grow almost every tropical product. ${ }^{64}$

The nationalistic tone of these pamphlets reflected the Australian public debate regarding the annexation of the New Hebrides at the time; evidence of this argument can be also be noted in ordinary travel accounts. For example, Thomas's account in 1886 used the natural resources of the

62 Coffee, Forty Years on the Pacific, 108.

63 Max Quanchi, 'Jewel of the Pacific and Planter's Paradise: The Visual Argument for Australian Sub-Imperialism in the Solomon Islands', The Journal of Pacific History 39, no. 1 (2004): 43-58, doi.org/ 10.1080/00223340410001684840.

64 Australasian New Hebrides Company, Australia and the New Hebrides (Sydney: Australasian New Hebrides Company, 1899), 6. 
Islands as a justification for their annexation: 'If this were a sample of the soil of the New Hebrides, and if it would last, and not become impoverished, the islands were certainly worth annexing. ${ }^{65}$

Popular notions of a prosperous settler's life in the New Hebrides continued into the early 1900s. BP attempted another settlement scheme in 1902, when Paterson was invited to accompany the settlers and report on their progress. ${ }^{66}$ His account romanticised these men and their journey, which he termed the 'Pilgrims' Progress' in his series for the Sydney Morning Herald in July 1902. He described them as 'bona-fide settlers, hardhanded, anxious faced men: they all have a little capital to lose, and they feel the responsibility of their undertaking very keenly ${ }^{67} \mathrm{He}$ returned to Sydney confident that:

Anything that could be done by a middle-aged Frenchman with a slightly protuberant outline could surely be done by these hardhanded men who had milked cows and shorn sheep and watched over travelling mobs of cattle on the dry stages of the outback. ${ }^{68}$

Paterson's account was not the only one that issued a challenge to enterprising Australian readers. Grimshaw also described 'a veritable gold-mine of copra' in Tanna; although she was concerned about local political instability, she framed this volatility as a challenge to entice readers into action:

These are the things that mere schoolboys of the British race can do, when you take them away from the grandmammas and aunts at home, and turn them loose in the wilderness to shift for themselves. ${ }^{69}$

Accounts that described the resilience of the Australian trader or planter acquired particular significance in the New Hebrides, where opponents to French rule represented the trader or planter as an innocent victim who was subject to 'one of the most inefficient and unfair systems of government in the civilised world' ${ }^{70}$ However, they also fuelled a broader theme of the 'pioneer planter', who colonised and pacified the Pacific Islands in general. ${ }^{71}$

65 Thomas, Cannibals and Convicts, 180.

66 Buckley and Klugman, The History of Burns Philp, 101.

67 Andrew Barton Paterson, 'The New Hebrides: Voyage of the Pilgrims', Sydney Morning Herald,

1 July 1902, 5, nla.gov.au/nla.news-article14468684.

68 Paterson, The Land of Adventure.

69 Grimshaw, From Fiji to the Cannibal Islands, 312, 198.

70 Marshall, The Black Musketeers, 284.

71 Bennett, Wealth of the Solomons, 109. 
Ultimately, tariffs, British restrictions of labour recruiting, and settlers' lack of capital contributed to the failure of these early settlement schemes. By the 1910s, the French both outnumbered and out-traded the British and Australians. According to Australian resident (and government spy), Wilson le Couteur, there were approximately two French residents to every one English resident in the New Hebrides in 1908. ${ }^{72}$ Australian and French allegiance to the Allied cause in World War I also prompted a decline in Australian interest in the New Hebrides. Although public hysteria about the New Hebrides eventually dissipated, some travellers continued to describe the Island group's economic potential in the 1920s and 1930s. With the 'promise to yield handsomely in the near future', Coffee argued, 'The New Hebrides are truly a paradise for planters, and only await a different form of government to make them a desirable place to settle in. ${ }^{73}$ Whether in Fiji, Nauru, Banaba, the Solomon Islands or the New Hebrides, the alluring myth of Pacific Island riches and resources continued to resonate among Australians, despite the increasingly harsh economic realities of Pacific commerce and trade.

\section{Confronting the Realities of Australian Enterprise}

Although the bulk of Australian travel writing presented a romantic view of Australian enterprise in the Pacific, some travellers acknowledged the difficulties that workers faced. For example, in 1886, Thomas noted that disease, fear of death and fluctuating copra prices were factors that made a copra trader's life difficult. ${ }^{74}$ In 1915, J Mayne Anderson's voyage to the New Hebrides left him with the impression that 'altogether here, as in most countries, the lot of the man on the land is not entirely free from care. ${ }^{75}$ In 1937, Marshall further observed that 'prolonged isolation and monotony have extraordinary effects upon some men' ${ }^{76}$ Unlike the lone pioneers of nineteenth-century trading tales, commercial development in the region by the twentieth century entailed that individual workers faced more competition, regulation and public scrutiny than ever before. ${ }^{77}$

72 Wilson le Couteur, 'The New Hebrides: Old Order and New: French Strides Forward', Sydney Morning Herald, 29 August 1908, 8, nla.gov.au/nla.news-article15021313.

73 Coffee, Forty Years on the Pacific, 106.

74 Thomas, Cannibals and Convicts, 245.

75 Anderson, What a Tourist Sees in the New Hebrides, 51.

76 Marshall, The Black Musketeers, 291.

77 Bennett, Wealth of the Solomons, 220. 
Close encounters with these Australian workers in the Islands usually stimulated a more realistic portrayal of their characters in travel writing. Not all traders and planters were necessarily heroic, as the Pacific attracted those with criminal backgrounds or opportunists who were broke or desperate. ${ }^{78}$ Many workers could appear quite ordinary, as Caroline David observed when meeting an Australian trader in Funafuti in 1897:

He was not the sort of man that we expected the trader to be: he was neither a low-down ruffian, nor a romantic, adorable scamp, like some novelists' creations; he was just a normal, decent fellow. ${ }^{79}$

In his close encounters with the 'farmers, prospectors, labourers, bushmen, and tradesmen' who participated in a settlement scheme in the New Hebrides, Paterson noted that these men were 'well seasoned to the world's affairs' and that they were very discerning:

They are decidedly cool-headed men, very unwilling to believe anything till they see it. They seem to have had hard experiences in their lives, and they take all the statements with a grain of salt. They hold a sort of Parliament in the fore-hatch each day, and talk over the maps and pamphlets they have got; also they crossexamine the missionaries who are on board ... the French settlers question also troubles their minds a good deal, as they think the French will resent their coming. ${ }^{80}$

These people were uninterested in romantic notions of defending the Australian nation, wrote Paterson; he further noted that 'they want money now, not glory here-after'.

Although some travellers questioned the popular stereotypes underlying these heroic figures, it was the travel accounts of Australians who worked in the Pacific Islands that offered the clearest insights. These Australians possessed 'an astonishing knowledge of the most intimate affairs of his neighbours for several islands around' ${ }^{81}$ Four accounts are illustrative here- two by traders (John Ernest Philp and Joseph HC Dickinson), one by a gold prospector (John Archibald Fraser) and one by a plantation overseer (Walter Gill). These accounts demonstrated the difficulties of commerce that were experienced in the Pacific, despite the popular

78 Bennett, Wealth of the Solomons, 58.

79 Edgeworth David, Funafuti, 131.

80 Paterson, 'The New Hebrides: Voyage of the Pilgrims', 5.

81 Marshall, The Black Musketeers, 289. 
romanticising of a life of freedom and wealth. Although it can be argued that some of these writers were residents, it is also true that their visits were temporary and that their accounts described the experience of travel within the Islands. As such, they are considered part of the broad and ambiguous category of travel writing.

Philp's unpublished log recorded his daily life as a roving trader in the Solomon Islands during the 1910s. Philp had worked as a railway surveyor in Tasmania before leaving his wife and family in 1912 to be a copra trader and labour recruiter in the Solomon Islands for two years. ${ }^{82} \mathrm{He}$ arrived in the Pacific eight years after the labour trade in Queensland had been terminated. Philp would thus have been aware of the heroic and villainous representations of labour recruiters during the fierce public debate about the Queensland labour trade in the late nineteenth century.

Philp's account of his travels through the Solomon Islands was marked by a certain mundanity that was distinct from published accounts. Although he read other popular travel accounts (including those of Grimshaw and Becke), his own account contained short and simple observations that consisted of little embellishment or personal reflection. In fact, he was critical of the popular accounts of amateurs who drifted through the Islands. He called US author Jack London's description of the Solomon Islands a 'piffle', noting that it was 'reckoned a huge joke' by the residents. ${ }^{83} \mathrm{He}$ also crossed the paths of several other travel writers, including those of Martin and Osa Johnson (US authors and filmmakers), that of Clifford Collinson (British author) and those of Muspratt and Dickinson (Australian workers). Philp's log has since been used to highlight the exaggerations and inaccuracies that are contained within these travel accounts. ${ }^{84}$

Philp's experience of the Solomon Islands was generally positive, diverging from the conventional notions of hostile and savage Melanesians. Apart from some difficulties that he experienced when trading with locals whom he described as 'cheeky' or 'hard bargainers', Philp himself rarely experienced violence (noting that his recruits were 'all very jolly'). ${ }^{85}$ Though he recalled many past events of conflict at each Island that he

82 John Ernest Philp, A Solomons Sojourn: J. E. Philp's Log of the Makira, 1912-1913, ed. Richard Allen Herr and E Anne Rood (Hobart: Tasmanian Historical Research Association, 1978).

83 Philp, A Solomons Sojourn, 112.

84 As described by Richard Allen Herr and E. Anne Rood in Philp, A Solomons Sojourn, 15.

85 Philp, A Solomons Sojourn, 42, 88, 93. 
visited, the Islanders and Europeans were more familiar with one another by 1912 . His prosperous time in the Islands was not always shared by the resident traders and plantation overseers whom he visited, including Dick Richardson, Frank B Rigby and Dickinson. His interactions with them demonstrate that Europeans were vulnerable to violence, illness and commercial strife. As Bennett's history of the Solomon Islands revealed, European residents were susceptible to local politics, to competition with other traders, planters or prospectors, and to conflict with other resident Europeans (especially missionaries). These European residents were also constrained by government regulations; they were often beholden to their investors or to employers in Australia. Fluctuating trade prices and shifts in supply and demand, both in Australia and in the Islands, could have had devastating effects as well. ${ }^{86}$

Dickinson's account, like Philp's, also stressed the hardships that he faced as a resident trader, planter and labour recruiter in the Solomon Islands in the 1910s and 1920s. Typical of many peripatetic workers in the Pacific Islands, Dickinson regularly travelled between Australia and various Islands, so it is difficult to assess whether his account should be counted as travel writing. Although his A Trader in the Savage Solomons (1927) was a more exciting and exaggerated account that was published for a wider audience, he framed the account as a response to the negative depictions of traders:

There are missionaries, authors and American movie artists, who present to civilization a given type of white man who serves them as an asset for the collection of dollars. The South Sea trader is generally made to lend the colour. We see or hear of him exploiting the natives, and committing all kinds of villainy. Native girls are his pet diversion. A blackguard of the deepest dye. You may even see him knocked down on the movies by an admirable hero, and just in the nick of time. ${ }^{87}$

Dickinson argued instead that 'the trader in everyday life is the least able to defend himself'. ${ }^{88}$ His experience stressed the vulnerability of the white trader and of his role as a mediator in the Islands, in which he often deftly negotiated with potentially hostile Islanders. He was aware of the conflicts between Europeans and Islanders, as well as the internal tribal

86 Bennett, Wealth of the Solomons, 46-54.

87 Dickinson, A Trader in the Savage Solomons, 80.

88 Dickinson, $A$ Trader in the Savage Solomons, 81. 
feuds. In one example from March 1909, he described the process of negotiating a truce during a Malaitan war council to prevent a revenge attack on a corrupt German resident. He also described encounters with local residents, noting that the most common struggles that they faced were debt and misunderstandings with Islanders. ${ }^{89}$

Although Dickinson may have presented his work as an authentic depiction of life in the Pacific Islands, his impressions are distinct from those of Philp's because he often portrayed himself as heroic. This was most clearly demonstrated when he described the Union Jack that flew above the British governor's residence in the capital, Tulagi:

It floats high above the tree-tops in a little-known, savage land; for it signifies protection over its people, along with the advanceguard of pioneers, and those which follow them ... Beneath its shadow the pioneer and settler knows that there should be one of the Empire's representatives, who, traditions have taught them, will reflect what the flag stands for, and who, when they are in need, will extend assistance, sympathy and encouragement. ${ }^{90}$

Perhaps this patriotic emphasis explains why Dickinson did not mention any quarrels with British officials or missionaries—in fact, he had praised them. His heroism was further supported by his observations of Pacific Islanders, which repeated the usual stereotypes of Melanesian savagery.

Fraser's travel impressions while prospecting for gold offers a more nuanced account of Fijians and of Australian mining endeavours in Fiji during the 1930s. Born in Victoria, Fraser was an experienced miner who visited Fiji twice as a gold prospector. He first travelled to Tavua for nine months in 1933, then again with his brother in 1935, during which time he travelled extensively around Viti Levu. Gold was discovered in Viti Levu in 1932, and by 1935, there were 22 gold mining companies in Fiji, most of which were financed in Australia; this included the two most dominant companies, Emperor Gold Mining Company and Loloma Gold Mines. ${ }^{91}$ After a year in Fiji, Fraser prospected in Guadalcanal in the Solomon Islands, but returned to Australia unsuccessful. Following his death in World War II, his manuscript was published posthumously in 1954 under the title Gold Dish and Kava Bowl. Fraser's account offers

89 Dickinson, A Trader in the Savage Solomons, 111, 118.

90 Dickinson, A Trader in the Savage Solomons, 29-30.

91 Thompson, Australia and the Pacific Islands in the Twentieth Century, 20-1. 
insights about the practices of prospecting, the constant disappointment that miners experienced, the struggles of living and working with little financial support, the isolation that was felt, the conflict among miners that was experienced and the fervour that drove many inexperienced Australians and New Zealanders to try their luck. He wrote:

Gold-seeking in these scattered island-groups had its difficulties. Their distance from main centres of industry, the rugged and jungled nature of the country, the tropical climate with its scorching heat and drenching rains, and the prevalence of malaria and other tropical diseases all combined to make the search for gold a costly and hazardous enterprise. ${ }^{92}$

Despite these difficulties, Fraser enjoyed living abroad and the opportunity for intimate encounters with Islanders. When he was not prospecting at work, Fraser was actively travelling to local villages, exploring along the coast and in the mountains and conversing with his Islander workers:

There was also a language to be learned, and a happy and likeable race of people to become better acquainted with, who still retained enough loyalty to their old traditions to make them intensely interesting. ${ }^{93}$

He maintained good relations with the 'boys' who worked for him and considered them excellent craftsmen and workers, 'kindly, courteous, patient, and good-tempered'. Contrary to many accounts of allegedly lazy and indolent workers, Fraser described them as hard working, even competing among themselves to determine who could lift the heaviest load. ${ }^{94}$

Fraser also travelled through inland Fiji and gained a more thorough understanding of indigenous Fijians than most tourists did. In doing so, he sympathised with the plight of the Fijian:

I think that a white man coming to know the Fijian well might sometimes feel, as Kipling's soldier did about brown-skinned brother: 'You're a better man than I am, Gunga Din!'”5

92 Fraser, Gold Dish and Kava Bowl, 239.

93 Fraser, Gold Dish and Kava Bowl, 93.

94 Fraser, Gold Dish and Kava Bowl, 81-2, 97.

95 Fraser, Gold Dish and Kava Bowl, 131. 
He noted that ownership of land was often a cause of Islander dissension, though he also conceded that it was a difficult job for government surveyors to resolve. His admiration of Fijian villages contrasted his distaste for the urban environment of Suva. Specifically, he was critical of ignorant Australian tourists there. On one occasion, he observed a Methodist ship from Australia that unloaded 400 passengers to celebrate the Church's centenary, who consumed the village's entire stock of food in the process. ${ }^{96}$ His reflection on whether any tourists ever send the photos that they take back to the Islands was unusual for his time. ${ }^{97}$ Fraser's sensitive account of Fiji and his overall harmonious experience with the Islanders contradicted popular tales of Australian miners who battled hostile tribes in the Pacific, as well as romantic notions of Australians finding untold riches in the Islands.

Idealistic preconceptions of commerce in the region overlooked the violence and abuse of Pacific labourers that frequently occurred under the supervision of white planters and overseers. Many of the plantations were in remote rural areas, where such abuses could be carefully hidden from plain view, and few travellers could stay long enough to observe the relationships between white supervisors and their local subordinates. This explains why Australian travel writing offers few details about certain operations, such as those of CSR, a vast organisation that employed many Australians to work in Fiji. Instead, historians like Michael Moynagh have used company archives to understand how CSR 'demanded of their subordinates hard work, honesty and, above all, dedication to the company', with Brij $\mathrm{V}$ Lal illuminating how the exploitative policies of CSR affected the lives of Indian indentured labourers in Fiji. ${ }^{98}$ The account of Walter Gill, who worked as an overseer from 1915 to 1926 , draws attention to the difficulty that Australian employees experienced in satisfying the demands of their employers and in maintaining control over a local labour force in the Islands. Published in 1970 with the benefit of hindsight and a more progressive readership, Gill's recollections of sexual liaisons, abuse and physical violence are useful for considering the issues that were omitted or disguised in travel accounts, as well as the difficulties that Australians experienced in negotiating and justifying colonial relationships abroad.

96 Fraser, Gold Dish and Kava Bowl, 213.

97 Fraser, Gold Dish and Kava Bowl, 68.

98 Michael Moynagh, Brown or White?: A History of the Fiji Sugar Industry, 1873-1973 (Canberra: Pacific Research Monograph, The Australian National University, 1981), 28; Lal, Broken Waves. 
Gill recalled that his experiences were very challenging; he had significant responsibilities and struggled to maintain an obedient and efficient Indian labour force that had been imported by the British to work on Fiji's sugar plantations from 1879 to 1916 . In his early 20s, Gill was young, naive and unaware of the complex racial and religious divisions that existed among the workers. He held a disparaging view of most of the workers, describing them as 'feral unpredictables', 'apes' and 'cramped maggots in cell-like hutments'; he often felt isolated and vulnerable as the lone white man among them, noting, 'I lived in their jungle as one of them'. 99 Incidences of violence were common, such as one fight in which Gill disarmed a worker who threatened him with a knife. Moynagh has shown that:

Growers saw the overseer as a man who acted arbitrarily, who demanded of them work which they were reluctant to perform, and who used brute force at times to ensure that his orders were carried out. ${ }^{100}$

Additionally, Gill described the numerous instances of suicide, murder, sexual abuse, prostitution, disease, drunkenness and a constant power struggle between 'sirdars' (Indian supervisors) and European overseers.

Gill also documented his struggle to satisfy the demands of CSR and to implement his required role in a business with which he had begun to disagree fundamentally. Gill increasingly felt alienated from the company and other Europeans, writing that 'among my own countrymen I had made few friends; a pattern which was to remain constant over the years'. ${ }^{101}$ This disillusionment, compounded by the close relationships he developed with some of his employees, forced Gill to reconsider the merits of indentured labour:

If we, the overseers and sirdars caught up in the rotten system of indenture servitude fathered by Big Business on that most fecund of whores, cheap Asiatic labour, had managed to survive in the tooth-and-claw jungle of the cane game, it was only by outanimalizing the horde of near-human apes in our charge. ${ }^{102}$

99 Gill, Turn North-East at the Tombstone, 38.

100 Moynagh, Brown or White?, 130.

101 Gill, Turn North-East at the Tombstone, 32.

102 Gill, Turn North-East at the Tombstone, 65. 
It is unclear whether this reflects the pressures of the working environment at the time or a more conciliatory attitude that was made in hindsight to defend his actions. Nonetheless, Gill's account draws attention to the darker and exploitative side of Australian commercial enterprise in the Pacific, which conventional travel writing has avoided.

Travel writing by 'enterprising' Australian workers in the Pacific must be carefully examined for what it omits—notably these workers' relationship with women. Sexual liaisons between European men and local women (including Islanders and other non-Europeans) were notable only for their omission from most Australian travel accounts, likely because it was a subject of impropriety. Images of the Pacific often separated the white men from Pacific women, and it was unusual for travellers to publish photographs of intimate interracial mixing. British traveller Richard Reynell Bellamy believed that progressive French attitudes to 'sex and other veiled subjects' were superior to the British 'hush-hush attitude'. ${ }^{103}$ Although intimate encounters between Australian workers and Islanders were rarely recorded, it is important to understand that 'sex, commerce and labour are inextricably connected in these networks of exchange'. ${ }^{104}$ Travellers' observations of 'half-castes' and venereal diseases in the Pacific also highlight the prevalence of these sexual encounters.

Although tourists visiting the Islands imagined sexual transgressions, these intimate encounters tended to be more common among longterm residents than temporary visitors. This was due to the nature of employment in the Islands, as traders, planters and overseers were in regular contact with local females. This is reflected in the numerous descriptions of the trader or planter and his 'native wife'. ${ }^{105}$ Sydney Walter Powell was surprised when he met a couple in the Tuamotus and realised that she 'was not the shrinking half-wild creature commonly presented in South Sea stories as "the trader's wife"'. ${ }^{106}$ In fact, popular fictional tales of traders in the Pacific did not always employ 'native' women as tools to reinforce traditional gender roles. Such ambiguities and contradictions have even been found in the works of Becke. ${ }^{107}$

103 Bellamy, Mixed Bliss in Melanesia, 118.

104 Dixon, Writing the Colonial Adventure, 185.

105 Gunga, Narrative of a Trip from Maryborough to New Caledonia, 18; Osborne, Through the Atolls of the Line, 9; Irwin and Goff, No Longer Innocent, 47.

106 Powell, Adventures of a Wanderer, 232.

107 Sturma, South Sea Maidens, 110-11; Thomas and Eves, Bad Colonists, 144. 
The marriage of European workers and residents to non-Europeans in the Islands was generally not frowned upon in Australian travel writing because the life of a trader or planter was acknowledged as lonely and 'to take a white wife there is also almost impracticable'. ${ }^{108}$ However, bringing wives to Australia could create complications, as Joseph Hadfield Grundy observed when he met a 35-year-old trader who married a 'native woman', but who remained in the New Hebrides because she 'could not live in Australia being as Asiatic'. ${ }^{109}$ These interracial relationships were not always sustainable, nor were husbands or wives necessarily expected to be lifelong partners. Dickinson fell in love with one woman, Tora-kene, but soon abandoned her in response to threats from other Islanders. ${ }^{110}$ Becke married Nelea Tikena in Kiribati in 1881, but did not bring her to Australia, and then remarried soon after returning home. ${ }^{11}$ SafroniMiddleton noted in 1915 that it was common for both European men and Islander women to have multiple partners. ${ }^{112}$ These instances reveal the complexities of cross-cultural encounters that unsettled the simplified stereotype of the Australian male worker in the Pacific Islands. They also highlight the vulnerabilities of the supposedly heroic trader, planter, overseer and prospector as he tried to navigate the expectations and moral codes of two different worlds.

Due to its close proximity to the Pacific, Australian commercial enterprise in the region played a significant role in the new nation's development. For the well-established colonial powers of France, Germany and Great Britain, commercial activities in the Pacific were regarded as being within the context of much larger global networks; as such, the Pacific Islands were often marginalised or overlooked. Economic ventures were often small in scale, and short lived, with the distance from Europe reducing profit margins, making communication difficult and discouraging prospective settlers. For colonial Australians in the late nineteenth century, the Pacific was closer and more lucrative. It is thus unsurprising that opportunistic travellers who sought employment or fortune preceded the holiday-makers and tourists. Pacific commerce was so important to the Australian colonies that those who made the journey became trusted sources of information. The literary legacy of Louis Becke is a testament

108 Grundy, The New Hebrides Group of Islands, 6.

109 Grundy, The New Hebrides Group of Islands, 6.

110 Dickinson, A Trader in the Savage Solomons, 80.

111 Sturma, South Sea Maidens, 112.

112 Safroni-Middleton, Sailor and Beachcomber, 150. 
to this; his distinct representations of the trader or planter in the Pacific formed the foundation for a broader imagining of the Pacific as a region of economic potential that was privileged for Australians. The archetype of the European trader was modified into the figure of the enterprising Australian in the early twentieth century. This individual reflected the nationalistic, masculine and racial ideals that existed within Australian society at the time. He also served as a convenient tool for promoting commercial development in the Pacific. Australian governments and businesses used travel writers and travel literature to encourage investment and public interest in the region by framing the Islands as available and rich in natural resources. In doing so, they portrayed Australia as an emerging centre of the region.

Closely analysing the firsthand accounts of these Australian travellers who sought economic prosperity in the Islands reveals that reality rarely met expectations and that the enterprising Australian was often vulnerable and unsuccessful rather than heroic. Nonetheless, the promise of a profitable Pacific remained consistent throughout the early twentieth century. Although readers of the interwar period grew weary of the market's saturation with predictable travel literature, the lived experiences of Australian workers in the Pacific continued to be considered a sign of authenticity. They privileged their accounts above the momentary observations of the steamer tourist. For audiences living abroad, stories of Australian enterprise in the Pacific continued to satisfy a market for the 'colonial exotic', as well as provide information about rapidly changing economic developments in the region. In times of economic hardship or instability, these stories offered hope to Australian readers. 
This text is taken from Australian Travellers in the South Seas, by Nicholas Halter, published 2021 by ANU Press, The Australian National University, Canberra, Australia.

doi.org/10.22459/ATSS.2021.05 